\title{
The Use of $\left[{ }^{14} \mathrm{C}\right]$ Amino Acids to Study Sites and Rates of Antibody Synthesis in Living Hyperimmune Rabbits
}

\author{
BY J. H. HUMPHREY AND B. D. SULITZEANU* \\ National Institute for Medical Research, Mill Hill, London, N.W. 7
}

(Received 28 December 1956)

Evidence for antibody production in various organs and tissues of immunized animals has been obtained in the main by three different methods. The first used (e.g. Pfeiffer \& Marx, 1898) was to show that antibody could be found in particular tissues in higher concentrations than in the blood plasma at the same time. The theoretical objections to this method, namely, that high concentrations of antibody might occur by some process of local accumulation rather than of synthesis, have been met by Oakley's comparison of the responses to two different antigens injected at separate sites (McMaster \& Hudack, 1935; Ehrich \& Harris, 1942; Oakley, Warrack \& Batty, 1949).

The second method has been to show that tissues from an immunized animal can produce antibodies either in vitro (e.g. Fagraeus, 1948; Askonas \& White, 1956; Stavitsky, 1955) or after transplantation to another host (e.g. Topley, 1930; Oakley, Batty \& Warrack, 1951; Sterzl, 1955).

The third has been the elegant fluorescentstaining technique of Coons, whereby antibodycontaining cells can be directly demonstrated in histological preparations (Coons, Leduc \& Connolly, 1955).

Although many antigens have been used, administered to different species of animal by different routes and for varying periods of time, results obtained by the three methods agree in pointing to the spleen, lymph nodes, bone marrow and (sometimes) the tissues at the sites of injection as being those chiefly involved in antibody synthesis. Most of the studies have been concerned with establishing the importance of a tissue or a particular type of cell in such synthesis.

We were interested to see whether it might be possible to determine the actual rates and amounts of antibody production by different tissues in living immunized animals, and to get some idea of the time required for synthesis of antibody molecules and for their appearance in the blood stream. Although studies on hyperimmune rabbits are of limited interest only, such questions are of relevance to the general problem of protein metabolism in higher animals; and antibodies, because

* Present address: Department of Bacteriology, Hebrew University, Hadassah Medical School, Jerusalem. of the ease with which they can be isolated specifically in small amounts from complex mixtures, provide unique material for such a study.

General plan of the work. Rabbits were immunized by intravenous injections of killed pneumococci type 3 over periods of several weeks, until the serum-antibody level was high and, as nearly as possible, steady. Under these conditions, the overall rates of production and degradation of antibody are constant and equal, and we assumed that each antibody-producing tissue was synthesizing and liberating antibody into the circulation at a steady rate. A mixture of uniformly labelled $\left[{ }^{14} \mathrm{C}\right]$ amino acids was then administered intravenously to a series of rabbits, and at various time intervals thereafter the animals were killed, bled and rapidly perfused with Ringer solution. A mixture of uniformly labelled amino acids was purposely chosen in the hope that variations in behaviour of individual amino acids would be evened out.

The antibody was extracted from different tissues, isolated by specific precipitation, and its specific ${ }^{19} \mathrm{C}$-radioactivity compared with that of the plasma antibody, and of the free amino acid pool in the plasma and the tissues. Owing to the uncertainty introduced by the fact that tissue antibody is derived partly from intracellular antibody and partly from trapped lymph, it was necessary to be able to correct for the lymph contribution. This was done by administering, several days beforehand, a quantity of antibody of the same kind which had been labelled with ${ }^{131} \mathrm{I}$. The ${ }^{131}$ I-labelled antibody mixes with circulating antibody, becomes distributed in the same way between plasma and lymph, and is broken down at the same rate (Humphrey \& McFarlane, 1954; Cohen, Holloway, Matthews \& McFarlane, 1956). The ${ }^{131}$ I-labelled breakdown products are promptly excreted, and there is never any appreciable quantity of ${ }^{131}$ I-labelled intracellular antibody. Hence by measuring the ${ }^{131}$ I-activities of the antibody recovered from tissue extracts, and of the plasma antibody obtained at the same time, an accurate estimate of the extracellular antibody could be made. 
Corrections, which are described below, had also to be made for completeness of recovery of antibody, and for contamination with other materials. Furthermore, since we attempt to relate the specific radioactivity of intracellular antibody to that of the plasma free amino acids, it was necessary to determine the relationship between the latter and the free amino acids of the tissues. Finally, since other non-protein materials besides amino acids become labelled, we had to investigate to what extent the non-protein radioactivity of plasma was derived from the injected amino acids and to what extent from their metabolic products.

The results have been used to attempt to calculate rates of synthesis of antibody in different tissues of the whole animal. Because of the numerous corrections and assumptions involved, the calculations are only very approximate. Their significance is assessed in the discussion.

\section{MATERIALS AND METHODS}

Animals. Adult white or sandy lop rabbits were used. They were bred at the National Institute for Medical Research, London, and were maintained on pelleted diet no. 18 (Bruce \& Parkes, 1940), supplemented with hay.

Antigens. Formalin-killed type 3 pneumococci, prepared according to Kauffman, Björneboe \& Vammen (1938), were used for immunization. Type 3 capsular polysaccharide, prepared according to Heidelberger, Kendall \& Scherp (1936), was used in precipitation tests

Immunization of rabbits. Pneumococci were injected intravenously, at 2- to 3-day intervals, in one or more courses of about 1 month, until a level of at least $5 \mathrm{mg}$. of antibody $/ \mathrm{ml}$. of serum was obtained. The injections were continued until 1 or 2 days before the experiment, to ensure that antibody production was maintained at a steady rate. Unpublished results of experiments showed that the rate of production of antibody against capsular polysaccharide began to fall off within about 4 days of the last intravenous injection of pneumococci. At least $90 \%$ of the precipitating antibody produced is directed against the capsular polysaccharide.

\section{Procedures for immunization and isolation of antibody}

Two or more rabbits were used in each experiment, except in the preliminary work, in which only one rabbit was used. Sodium iodide was added to the drinking water (50 mg./l.) 2-4 days before the experiment in order to dilute inorganic ${ }^{131} \mathrm{I}$, liberated by breakdown of the labelled protein, and so to minimize 131I-uptake by the thyroid. Rabbit serum, containing anti-pneumococci type 3 antibody, or a purified pneumococci type 3 antibody fraction, was labelled with ${ }^{131} I$ by the rapid mixing method of McFarlane (1956). Into the ear vein of each rabbit, 250$500 \mu \mathrm{C}$ of ${ }^{131}$ I-labelled anti-pneumococci type 3 antibody was injected. The specific activity was approx. $10 \mu \mathrm{c} / \mathrm{mg}$. of protein. Blood samples were taken from the ear daily, or at other suitable intervals, until the experiment was completed.
Two to 4 days after the injection of the 131I-labelled antibody, the rabbits were injected intravenously with an acid hydrolysate of approx. $25 \mu \mathrm{c}(0.5 \mathrm{mg}$.) of uniformly ${ }^{14} \mathrm{C}$-labelled Chlorella protein, obtained from the Radiochemical Centre, Amersham (Catch, 1954). After hydrolysis and removal of $\mathrm{HCl}$ about $21 \mu \mathrm{C}$ of soluble material remained. A sample of blood was taken $3 \mathrm{~min}$. later. Serum or plasma was separated at $2^{\circ}$ and used for the estimation of radioactivity of ${ }^{14} \mathrm{C}$-labelled amino acids in the plasma. After a chosen interval of time the rabbit was again bled from the ear, injected with $5 \mathrm{mg}$. of heparin intravenously and anaesthetized with Nembutal. The thorax was immediately opened, the right auricle was removed and 2-3 1. of Ringer solution was perfused via the left auricle, the heart being used as a manual pump. This method resulted in a very efficient removal of the blood, but some tissue fluid was inevitably left behind.

These tissues were then removed and placed in ice: lung, bone marrow (obtained from the long bones), liver, spleen, appendix, lymph nodes (cervical, axillary, inguinal, mesenteric, popliteal). The tissues were cleaned from adhering fat, rinsed with cold tap-water, blotted, weighed and homogenized at $0^{\circ}$ in an Ato-Mix homogenizer (Measuring and Scientific Equipment Ltd., London), enough fluid being added to make a workable suspension. The fluid consisted of $0.9 \% \mathrm{NaCl}$ solution buffered with 0.015 M-sodium phosphate, pH 7, containing 1:10000 merthiolate. A $5 \%$ solution of $\gamma$-globulin prepared from normal rabbits was then added in the proportion of $10-40 \mathrm{mg} \cdot / \mathrm{g}$. wet wt. of tissue, with the purpose of limiting adsorption of antibody by the tissue fragments. The total volume of suspension at this stage was 3-15 times the volume of tissue taken.

Extraction of antibody. The antibody was extracted by freezing the suspensions at $-10^{\circ}$, thawing and centrifuging at $2^{\circ}$, at $3000 \mathrm{rev} . / \mathrm{min}$. for $30 \mathrm{~min}$. This procedure was repeated three times, with diminishing volumes of buffer for extraction. Between the first and second freezing the macerated tissues were ground in a mortar to ensure complete destruction of the cells.

The three extracts were pooled and centrifuged in a highspeed angle centrifuge, at $12000 \mathrm{rev} . / \mathrm{min}$. for $3-6 \mathrm{hr}$. in the cold, until absolutely clear. They were left overnight at $2^{\circ}$. If clear, antibody was precipitated as described below; if not, they were centrifuged again and left to stand for a further period. This was done in order to ensure that nonspecific precipitation would be avoided as far as possible.

Antibody precipitation. To the clear extracts was added a concentrated neutralized acid hydrolysate of serum proteins (120 mg. of amino acids and $72 \mathrm{mg}$. of $\mathrm{NaCl} / \mathrm{ml}$.), sufficient to give a final concentration of $20 \mathrm{mg}$. of amino acid/ml. This concentration did not interfere with specific precipitation, and almost completely prevented adsorption of radioactive free amino acids. The extracts were centrifuged after standing overnight (3000 rev./min. for $30 \mathrm{~min}$.). The amounts of antibody available were too small to allow accurate predetermination of the amount of antigen required for each extract. Antibody was therefore precipitated by stepwise addition of small amounts of antigen until no further precipitation occurred. Since precipitation in the antigen-antibody system in question is not inhibited by even a two- to three-fold excess of antigen, this procedure is unlikely to result in loss of antibody. After the last addition of antigen the extracts were left overnight 
at $2^{\circ}$ to complete the deposition of antibody, which was always somewhat fibrous. If certain extracts were left in the cold for longer periods, non-specific precipitates, recognizable by their different consistency, were sometimes formed. On the few occasions when, in spite of these precautions the precipitates were obviously contaminated with non-specific material, this was noted. No precautions were taken to remove complement.

Estimation of antibody. The antibody precipitates were washed twice in saline with $0.9 \% \mathrm{NaCl}$, followed by $50 \%$ (v/v) aq. methanol, methanol and finally ether; they were then dried and weighed. Alternatively, the precipitates were dissolved in $0.1 \mathrm{~N}-\mathrm{NaOH}$ and the antibody was estimated by measurement of the optical density at $280 \mathrm{~m} \mu$.

The precipitates contained $5 \%$ by wt. of capsular polysaccharide. Since this was often within the weighing error of the small amounts of antibody which we were handling, the contribution of the antigen was neglected throughout.

\section{Specific radioactivity of free amino acids in serum and tissues}

We did not attempt to isolate each amino acid individually, but only to estimate the average specific activity of the carbon in the free amino acid mixtures present in the samples. Since the technical problems involved were different for serum and for tissues the procedures used are described separately.

Plasma-free aminoacids. Two methods of estimation were used: In the first method (referred to as 'glycine dilution'), serum samples, usually fresh but occasionally after storage at $-10^{\circ}$ for a few days, were dialysed in cellophan sacs against three changes of equal volumes of distilled water. The diffusates were pooled, and the amino $\mathrm{N}$ in a measured fraction was measured by the naphthoquinone method of Russell (1944). The remainders of the diffusates were concentrated to a small volume by evaporation at $105^{\circ}$, and to them was added sufficient glycine to dilute the amino acid $C$ suitably for subsequent measurement of specific radioactivity. In order to make the dilutions, a factor had to be assumed for converting amino $\mathrm{N}$ into amino acid $\mathrm{C}$. The factor depends upon the composition of the amino acid mixture present in the serum, which may vary from sample to sample. We used the figure of amino $\mathrm{N} \times \mathbf{4 \cdot 4}$ for reasons given below.

The second method (referred to as 'ninhydrin- $\mathrm{CO}_{2}$ ') is based on the following considerations. Since the ${ }^{14} \mathrm{C}$ labelling of the amino acids administered was uniform, the specific activity of the terminal carboxyl $C$ should be identical with that of the total C. Furthermore, the terminal carboxyl $\mathbf{C}$ can be specifically liberated from free $\alpha$-amino acids by treatment with ninhydrin, and possible interference by other ${ }^{14} \mathrm{C}$-labelled metabolites is thereby eliminated.

Provided that the average carbon content of labelled amino acids in rabbit plasma is close to the average for the algal-protein hydrolysate, which is true if calculations are based on the values given by Duchateau \& Florkin (1954) for the composition of free amino acids in rabbit plasma, measurement of the specific activity of the terminal carboxyl $\mathrm{C}$ seemed likely to give the best estimate of the specific ${ }^{14} \mathrm{C}$-activity of the free amino acids. The disadvantage of the method was that large plasma samples were required to yield sufficient $\mathrm{CO}_{2}$ for estimation and counting. In certain instances, however, this method was used, 15-25 ml. of plasma being mixed with an equal volume of $10 \%(w / v)$ trichloroacetic acid, and treated in the manner outlined for the tissue extracts below.

Tissue-free amino acids. Since the cellular make-up of tissues of hyperimmunized rabbits may differ from normal, the animals were first subjected to one or more courses of pneumococci type 3 injections, so as to make them comparable with the animals used for antibody studies. Algal $\left.{ }^{[14} \mathrm{C}\right]$ protein hydrolysate was injected intravenously, and after a suitable time interval the rabbits were anaesthetized and immediately perfused via the left auricle with about 11. of ice-cold saline until the returning fluid was almost free from red cells. This took $2 \mathrm{~min}$. The organs were removed as rapidly as possible and placed in crushed ice, after which they were cleaned, weighed and dropped into liquid air. In order to obtain bone marrow, the long bones were freed as far as possible from muscle before immersing in ice; the bones were removed one at a time, the ends were cut off and the marrow expelled cleanly by applying compressed air to one end. The time between the end of the perfusion and immersion in liquid air was 2-3 min., except for bone marrow, which took 5-8 $\mathrm{min}$.

The frozen tissues were crushed and then ground with a volume in millilitres of $10 \%(w / v)$ trichloroacetic acid equal to their weights in grams. The resulting fine suspensions were centrifuged hard, and the supernatant fluid was extracted thrice with peroxide-free ether in order to remove trichloroacetic acid. The volume was reduced to 1-2 ml. by evaporation at $105^{\circ}$ and, after filtration to remove insoluble material, the tissue extract was treated with ninhydrin at $\mathrm{pH} 2.5$, and the free amino acid carboxyl $\mathrm{CO}_{2}$ collected in baryta by the technique of Van Slyke, McFadyen \& Hamilton (1941). In this technique it was necessary to use silicone antifoam (MS Antifoam A, Hopkin and Williams, Ltd., Chadwell Heath, Essex), since it became apparent in our earlier experiments that other antifoaming agents are liable to get into the counting tube and to cause quenching. The $\mathrm{BaCO}_{3}$ precipitate was transferred to one atm of a Rittenberg tube and an approximately equal volume of conc. $\mathrm{H}_{2} \mathrm{SO}_{4}$ was placed in the other arm $\left(\mathrm{H}_{2} \mathrm{SO}_{4}\right.$ was used instead of $\mathrm{HCl}$ in order to avoid getting $\mathrm{HCl}$ into the gas line). The $\mathrm{CO}_{2}$ was liberated and its specific activity was measured (see below). Liberation of $\mathrm{CO}_{2}$ was usually incomplete, and when quantitative recovery was required the $\mathrm{BaCO}_{3}$ was first washed thrice with $\mathrm{CO}_{2}$-free water, dried at $105^{\circ}$ and weighed.

Although this method measured free amino acids present in the lymph, besides those inside the cells, the independent measurements of contamination by lymph, made by means of [ $\left.{ }^{131} I\right]$ proteins, showed that extracellular amino acids could not have made up more than $5 \%$ of the total.

Measurement of radioactivity. ${ }^{131}$ I was measured by counting in a well-type scintillation counter of conventional design. The material to be counted was either in the form of a small dry pellet or dissolved in $3 \mathrm{ml}$. of dilute $\mathrm{NaOH}$.

Specific ${ }^{14} \mathrm{C}$-activities were measured after combustion to $\mathrm{CO}_{2}$ by the method of Bradley, Holloway \& McFarlane (1954). For measurements of specific activities of plasma free amino acids the materials were diluted with known amounts of carbon, added as glycine, sufficient to give a suitable volume of gas in the counter. In those instances 
where the activity of terminal carboxyl carbon only was measured, no dilution was made (the amounts of radioactivity injected having been chosen so as to yield samples with activities within the capacity of the counting equipment).

For greater ease of presentation the results are presented in two parts, the first dealing with antibody recovery and radioactivity, and the second with free amino acids in plasma and tissues. They are, however, considered together in the Discussion.

\section{RESULTS OF ANTIBODY STUDIES}

\section{Reliability of methods}

Recovery of antibody from tissues. Since the amounts of antibody present in the tissues were small, some losses were inevitable. Non-specific adsorption of antibody on to tissue debris was minimized by the addition of a large excess of normal rabbit $\gamma$-globulin. Significant binding by intracellular antigen is unlikely to have occurred, because the amounts of antigen injected were relatively minute and because antigen was not detectable in control material stained by the fluorescent-antibody technique of Coons \& Kaplan (1950). Nevertheless, it was important to know how efficient were the antibody recoveries. Although these could not be measured directly, an estimate was obtained by adding to tissues of normal rabbits known amounts of ${ }^{131}$ I-labelled antibody against capsular polysaccharide, in quantities comparable with those found in an average experiment, and attempting to recover the antibody in the usual way. Since the specific ${ }^{131}$ Iactivity of the added antibody was known, measurement of the specific activity of the recovered precipitate made it possible to estimate the extent to which the recovered antibody was contaminated with inert material.
The procedure of stepwise addition of antigen involved warming the tissue extracts at $37^{\circ}$ for a total of up to $2 \mathrm{hr}$. Since we feared that some destruction of antibody might occur during this period, the effect of heating lung and bone-marrow extracts for $6 \mathrm{hr}$. was also examined.

It will be seen from Table 1 that although the weights of precipitate recovered were usually little less than the weight of antibody added, there was a considerable admixture of non-antibody material which lowered the specific activity. This occurred especially when small amounts of antibody were present in large amounts of tissue (e.g. the appendix), so that the volumes of extract and the amounts of cell material were large. The result was to reduce the net recovery.

When bone marrow was incubated for $6 \mathrm{hr}$. the recovery was unchanged, but with lung it was $20 \%$ less, a reduction which was disregarded since the incubation period was at least three times longer than any used in practice.

In view of these results, it was clear that antibody extracted from tissues was liable to be contaminated with inert material and that extraction would be incomplete. Approximate corrections were therefore calculated, based on the mean values in the two control experiments, as shown in Table 1 .

Radioactive contamination of recovered antibody. The following experiment was performed in order to assess the extent to which antibody recovered from an immunized rabbit, after administration of [14 C]amino acid, had become labelled by adsorption of amino acids or of highly labelled cell proteins. To the tissue extracts of two of the animals of our series were added known amounts of unlabelled anti-ovalbumin. These were specifically precipitated by addition of ovalbumin, before the antibody to capsular polysaccharide was recovered in the usual way. Specific ${ }^{14} \mathrm{C}$-activities were

\section{Table 1. Recovery of antibody added to normal rabbit tissues}

The antibody added had been labelled with ${ }^{131}$ I. For recovery procedures, see Methods. Net recovery $=(w t$. recovered $x$ purity)/wt. added. Correction factors for losses during recovery from different tissues were calculated from the mean values of the corresponding percentages. Occasions when these factors were used are indicated in the text.

\begin{tabular}{|c|c|c|c|c|c|c|c|c|}
\hline \multirow[b]{2}{*}{ Tissue } & \multicolumn{2}{|c|}{$\begin{array}{l}\text { Amount of antibody } \\
\text { (mg.) }\end{array}$} & \multicolumn{2}{|c|}{$\begin{array}{l}\text { Specific activity } \\
\text { of antibody } \\
\text { (counts/min./mg.) }\end{array}$} & \multirow{2}{*}{$\begin{array}{c}\text { Purity of } \\
\text { recovered } \\
\text { antibody } \\
(\%)\end{array}$} & \multirow{2}{*}{$\begin{array}{l}\text { Net } \\
\text { recovery } \\
(\%)\end{array}$} & \multicolumn{2}{|c|}{ Correction factor for } \\
\hline & Added & Recovered & Added & Recovered & & & Purity & $\begin{array}{l}\text { Wt. } \\
\text { recovery }\end{array}$ \\
\hline Lung & $\begin{array}{l}19 \cdot 6 \\
10 \cdot 8\end{array}$ & $\begin{array}{r}17 \cdot 06 \\
7 \cdot 25\end{array}$ & $\begin{array}{l}53500 \\
16100\end{array}$ & $\begin{array}{l}45000 \\
12300\end{array}$ & $\begin{array}{l}84 \\
76\end{array}$ & $\begin{array}{l}73 \\
51\end{array}$ & $1 \cdot 25$ & $1 \cdot 3$ \\
\hline Bone marrow & $\begin{array}{l}9 \cdot 8 \\
5 \cdot 8\end{array}$ & $\begin{array}{l}8 \cdot 8 \\
4 \cdot 8\end{array}$ & $\begin{array}{l}51600 \\
16100\end{array}$ & $\begin{array}{r}36000 \\
8900\end{array}$ & $\begin{array}{l}\mathbf{7 0} \\
\mathbf{5 5}\end{array}$ & $\begin{array}{l}63 \\
46\end{array}$ & $1 \cdot 60$ & $1 \cdot 15$ \\
\hline Spleen & $\begin{array}{l}1.96 \\
1 \cdot 0\end{array}$ & $\begin{array}{l}1 \cdot 7 \\
1 \cdot 0\end{array}$ & $\begin{array}{l}51600 \\
16100\end{array}$ & $\begin{array}{r}30700 \\
8090\end{array}$ & $\begin{array}{l}60 \\
50\end{array}$ & $\begin{array}{l}52 \\
50\end{array}$ & $1 \cdot 82$ & 1.09 \\
\hline Appendix & $\begin{array}{l}1.96 \\
1.45\end{array}$ & $\begin{array}{l}1 \cdot 2 \\
0 \cdot 8\end{array}$ & $\begin{array}{l}51600 \\
16100\end{array}$ & $\begin{array}{r}30000 \\
4950\end{array}$ & $\begin{array}{l}58 \\
31\end{array}$ & $\begin{array}{l}36 \\
17\end{array}$ & $2 \cdot 20$ & $1 \cdot 71$ \\
\hline
\end{tabular}


measured, and those of the added anti-ovalbumin were only about $10 \%$ of those of the tissue debris and $1 \%$ of those of the antibody to capsular polysaccharide. Radioactivity due to non-specific adsorption was therefore insignificant.

As a further check, in another experiment the tissue extracts, after removal of antibody, were precipitated with trichloroacetic acid and the specific radioactivities both of the soluble nonantibody protein and of the insoluble tissue debris were measured. As will be seen in Table 2, the antibody radioactivities were about ten times greater than those of the remaining soluble material.

Correction for preformed extracellular antibody. Although most of the blood was removed by perfusion, there remained in the tissues an unknown amount of extracellular fluid whose antibody was inevitably mixed with any truly intracellular antibody present. This was allowed for in the following way. Two to 4 days before the animals were killed, 10-20 mg. of 131I-labelled antibody to capsular polysaccharide $(100-300 \mu \mathrm{C})$ was injected intravenously, and this became mixed with unlabelled antibody in the circulation. Since the 131I-label is promptly lost once the labelled molecules become intracellular and are catabolized, and since antibody molecules remain intact only so long as they are extracellular (apart, of course, from those actually in the synthesizing cells) (Humphrey \& McFarlane, 1954; Cohen et al. 1956), 131I-labelled antibody could be used as a marker for extracellular antibody. About 3 days after injection of ${ }^{131}$ I-labelled antibody, the specific ${ }^{131}$ I-radioactivity of the antibody in the plasma is almost equal to that in the extracellular extravascular fluid. Thus if the specific ${ }^{131}$-activity of the serum antibody at the time of death was $A$, and that of the antibody extracted from a tissue $B$, then suppose that there were $x$ and $y$ mg. of extra- and intra-cellular antibody respectively, then $B=x A$ / $(x+y)$ counts/min./mg.; hence $x /(x+y)=B / A$, and $(B / A) \times 100$ is the percentage of the tissue antibody which was extracellular.

In some of our experiments, the plasma antibody had become labelled with ${ }^{14} \mathrm{C}$ to a significant extent during the time which elapsed after administration of $\left[{ }^{14} \mathrm{C}\right]$ amino acids. Although the correction was small, it was made on the assumption that the ${ }^{14} \mathrm{C}$ label would be present in lymph antibody to the same extent as in the plasma (which is likely to be true for the very vascular tissues examined). Thus if $a$ and $b$ were the measured specific ${ }^{14} \mathrm{C}$-activity of the serum antibody and tissue antibodies respectively, and $p$ the calculated percentage of extracellular antibody in the tissue antibody (from the measurements of 131I), true specific activity of tissue antibody= $(100 b-p a) /(100-p)$.
In Table 3 are given representative figures for the calculated percentages of extracellular antibody present in different tissues in various experiments. They are very variable for two reasons. One is that the efficiency of perfusion was by no means uniform, and the other that when the amounts of antibody were very small the error in weighing total antibody was such that it was impossible, for example, to distinguish between extracellular antibody contributions of 90 or $100 \%$. Thus, in experiments with both ${ }^{131} \mathrm{I}$ and ${ }^{14} \mathrm{C}$, it sometimes occurred that by measurement of ${ }^{131} \mathrm{I}$ all the antibody from a tissue appeared to be extracellular, and yet the antibody specific ${ }^{14} \mathrm{C}$-activity was much higher than that of the serum antibody at the same time, indicating that part of the tissue antibody was actually intracellular. In such instances, however, no true estimate of the intracellularantibody specific activity could be made, and the values were not used in subsequent calculations.

\section{Table 2. Distribution of radioactivity in tissue fractions}

Non-antibody material and antibody against capsular polysaccharide were isolated from the tissues of a rabbit $0.25 \mathrm{hr}$. after injection of $85 \mu \mathrm{C}$ of $\left[{ }^{14} \mathrm{C}\right]$ amino acids. The specific activities of the resulting fractions are expressed as counts/min./mg. of $\mathrm{C}$.

\begin{tabular}{lccc}
\multicolumn{1}{c}{ Tissue } & Antibody & $\begin{array}{c}\text { non-antibody } \\
\text { protein }\end{array}$ & $\begin{array}{c}\text { Insoluble } \\
\text { debris }\end{array}$ \\
Lung & 6750 & 699 & 926 \\
Bone marrow & 7300 & 762 & 1318 \\
Spleen & 21200 & 665 & Not measured \\
Lymph gland & 7700 & 880 & 727 \\
Appendix & 7900 & 608 & 900
\end{tabular}

Table 3. Percentage of antibody found to be extracellular in tissue extracts after perfusion

Three days before the rabbits were killed they were injected intravenously with $100-300 \mu \mathrm{C}$ of ${ }^{131}$ I-labelled antibody. Antibody was subsequently isolated from the perfused tissues shown and also from the serum. Comparison of the specific activities of the former with those of the latter enabled the percentages of antibody, persisting in extracts of the perfused tissues, to be determined. The amounts of ${ }^{131}$ I-labelled antibody injected were sufficient to ensure that the measured radioactivities of the tissue antibodies were never less than $1 \frac{1}{2}$ times background, and usually very much higher.

\begin{tabular}{|c|c|c|c|c|c|}
\hline $\begin{array}{c}\text { Rabbit } \\
\text { no. }\end{array}$ & Lung & $\begin{array}{c}\text { Bone } \\
\text { marrow }\end{array}$ & Spleen & $\begin{array}{r}\text { Lymph } \\
\text { glands }\end{array}$ & Appendix \\
\hline 28 & 32 & 74 & 24 & 71 & 100 \\
\hline 24 & 30 & 100 & 91 & 63 & 17 \\
\hline 2 & 45 & 44 & 15 & 54 & 34 \\
\hline 19 & 38 & 25 & 8 & 50 & 35 \\
\hline 5 & 63 & 65 & 35 & 83 & 71 \\
\hline 23 & 56 & 41 & 10 & 66 & No antibody \\
\hline
\end{tabular}


Table 4. Antibody distribution in tissues of a rabbit immunized against two antigens

The percentages of extracellular antibody in the perfused tissues were determined in a similar manner to that described in Table 3, except that a mixture of two antibodies labelled with ${ }^{131} \mathrm{I}$ had been injected 2 days previously. The mixture was obtained by iodination of $1 \mathrm{ml}$. of the animal's own serum with $270 \mu \mathrm{C}$ of ${ }^{131} \mathrm{I}$. At the time of death the serum contained (per ml.) $10.7 \mathrm{mg}$. of anti-ovalbumin and $6 \mathrm{mg}$. of antibody to capsular polysaccharide.

\begin{tabular}{|c|c|c|c|c|}
\hline \multirow[b]{2}{*}{ Tissue } & \multicolumn{2}{|c|}{$\begin{array}{c}\text { Antibody extracted } \\
\text { (mg.) }\end{array}$} & \multicolumn{2}{|c|}{$\underset{(\%)}{\text { Extracellular antibody }}$} \\
\hline & $\begin{array}{c}\text { Anti- } \\
\text { ovalbumin }\end{array}$ & $\begin{array}{c}\text { Anti- } \\
\text { polysaccharide }\end{array}$ & $\begin{array}{c}\text { Anti- } \\
\text { ovalbumin }\end{array}$ & $\begin{array}{l}\text { Anti- } \\
\text { polysaccharide }\end{array}$ \\
\hline $\begin{array}{l}\text { Lung } \\
\text { Bone marrow }\end{array}$ & $\begin{array}{l}12 \cdot 5 \\
12 \cdot 1\end{array}$ & $\begin{array}{l}2 \cdot 6 \\
3 \cdot 5\end{array}$ & $\begin{array}{l}16 \cdot 8 \\
69\end{array}$ & $\begin{array}{l}20 \cdot 7 \\
74\end{array}$ \\
\hline
\end{tabular}

\section{Table 5. Levels of antibody and ${ }^{131}$ I-radioactivity in serum of rabbit in illustrative experiment}

About 20 mg. of antibody labelled with ${ }^{131} \mathrm{I}$ was injected intravenously, and blood samples were taken after 3 min., $24 \mathrm{hr}$., $48 \mathrm{hr}$. and $70 \mathrm{hr}$. The amount and radioactivity of the antibody in the serum was determined.

$\begin{array}{lcc}\quad \text { Date } & \begin{array}{c}\text { Antibody } \\ (\mathrm{mg} / \mathrm{ml} \text {.) }\end{array} & \begin{array}{c}\text { Specific } \\ \text { activity } \\ \text { (counts/min./mg.) }\end{array} \\ \text { 26. viii. } 55 & 9 \cdot 9 & 76500 \\ \text { 27. viii. } 55 & 9 \cdot 5 & 45300 \\ \text { 28. viii. } 55 & 9 \cdot 2 & 37900 \\ \text { 29. viii. } 55 \text { (killed) } & 9 \cdot 1 & 35100\end{array}$

An indication of the reliability of the ${ }^{131}$ I-label as a marker for extracellular antibody was obtained from an experiment in which a rabbit was used which had been simultaneously immunized by intravenous injection both of pneumococci type 3 and alum-precipitated ovalbumin. The rabbit received an intravenous injection of a ${ }^{131} \mathrm{I}$-labelled mixture of anti-capsular polysaccharide and antiovalbumin 2 days before extraction of the antibodies from lung and bone marrow in the usual way. Table 4 shows that although the absolute levels of the two antibodies differed widely, the percentage of extracellular antibody in the lung and bone marrow agreed closely for both kinds of antibody.

\section{Illustrative experiment}

In order to show how the results were arrived at, a typical experiment is summarized below. A rabbit, hyperimmunized against pneumococci type 3, was injected intravenously with about $25 \mathrm{mg}$. of a concentrate of rabbit $\gamma$-globulins labelled with ${ }^{131} \mathrm{I}$, in which $85 \%$ of the protein was specific antibody to capsular polysaccharide. The total activity injected was $91 \times 10^{6}$ counts $/ \mathrm{min}$. After $3 \mathrm{~min}$., a blood sample was taken, and $1 \mathrm{ml}$. of plasma was found to contain $0.892 \times 10^{6}$ counts/ min. The plasma volume was thus $102 \mathrm{ml}$. The plasma equivalent of lymph and plasma is about 2.5 times this value (Cohen et al. 1956). Further small blood samples were taken daily, and the amounts of antibody and its radioactivity were measured after specific precipitation. The results, given in Table 5, show: (a) that although the antibody level fell slightly, the animal was producing antibody almost as fast as it was being destroyed, i.e. it was in an approximately steady state; and (b) that after $48 \mathrm{hr}$., assuming that equilibration between plasma and lymph had occurred by then, the rate of disappearance of the labelled protein was $8 \% /$ day, consistent with the turnover rate of about $10 \% /$ day observed by Humphrey \& McFarlane (1954). These figures permit an approximate calculation of the daily rate of antibody production at the time of the experiment, namely:

wt. of antibody produced daily (mg.)

$=$ fraction renewed $\times$ concn. of antibody $\times$ plasma equiv. of plasma and lymph

$=0 \cdot 1 \times 9 \cdot 1 \times 250=228$.

Three days after the administration of ${ }^{131} \mathrm{I}$ labelled proteins, $21 \mu \mathrm{C}\left(0.5 \mathrm{mg}\right.$.) of algal [ $\left.{ }^{14} \mathrm{C}\right]$ protein hydrolysate was injected intravenously and $2 \mathrm{hr}$. later the animal was perfused, and its antibody obtained from its tissues as described above.

In Table 6 are given the amounts and radioactivities of the antibody precipitates obtained from various tissues and from the serum. These figures include a correction for the extracellular antibody, but the correction factors given in Table 1 have not been applied.

\section{Recovery of antibody from tissue extracts}

In Table 7 are recorded the amounts of antibody recovered in typical experiments, together with the values adjusted to allow for extracellular antibody. It will be seen that with few exceptions the lungs contained considerably more antibody than the other tissues, even when allowance is made for the fact that only part of the bone marrow or lymph glands was examined. The tissue with the next highest content was the bone marrow. Spleen, lymph glands and appendix all contained intracellular antibody, but significant amounts were never recovered from liver or kidney. 


\section{Table 6. Amounts and specific activities of antibody recovered in illustrative experiment}

The earlier procedure in this experiment is described in Table 5. Finally, 2 hr. before the same rabbit was killed, algal $\left[{ }^{14} \mathrm{C}\right]$ protein hydrolysate $(21 \mu \mathrm{c} ; 0.5 \mathrm{mg}$.) was injected intravenously. For subsequent procedures and for the corrections applied to obtain the values in the fourth and sixth columns, see the text and Table 3 respectively.

\begin{tabular}{|c|c|c|c|c|c|}
\hline Tissue & $\begin{array}{l}\text { Antibody } \\
\text { recovered }\end{array}$ & $\begin{array}{c}\text { Specific }{ }^{131} \mathbf{I} \\
\text { activity } \\
\text { (counts/min./mg. } \\
\text { of antibody) }\end{array}$ & $\begin{array}{c}\text { Extracellular } \\
\text { antibody } \\
(\%)\end{array}$ & $\begin{array}{l}\text { Measured } \\
\text { specific } \\
{ }^{14} \text { C-activity } \\
\text { (counts/min./ } \\
\text { mg. of C) }\end{array}$ & $\begin{array}{c}\text { specific } \\
\text { 14C-activity } \\
\text { of intracellular } \\
\text { antibody } \\
\text { (counts/min./ } \\
\text { mg. of } \mathrm{C} \text { ) }\end{array}$ \\
\hline Lung & $8.9 \mathrm{mg}$. & 16800 & 45 & 768 & 1220 \\
\hline Bone marrow & $3.5 \mathrm{mg}$. & 15300 & 44 & 259 & 375 \\
\hline Spleen & $1.5 \mathrm{mg}$ & 5320 & 15 & 1160 & 1340 \\
\hline Lymph glands & $0.5 \mathrm{mg}$. & 19000 & 54 & 136 & 174 \\
\hline Appendix & $0.5 \mathrm{mg}$. & 11900 & 34 & 118 & 126 \\
\hline Serum at $3 \mathrm{~min}$. & $9.1 \mathrm{mg} . / \mathrm{ml}$. & 35100 & - & 2 & - \\
\hline Serum at $2 \mathrm{hr}$. & $9.1 \mathrm{mg} \cdot / \mathrm{ml}$ & - & - & 105 & 一 \\
\hline
\end{tabular}

Table 7. Amounts of antibody extracted from the tissues of hyperimmune rabbits after perfusion

In each case column $A$ gives the actual amounts of antibody precipitate recovered, and column $B$ the amount which was calculated to be truly intracellular, as described in the text and Table 3. No corrections are made for losses in recovery (see text and Table 1). Since only about $6 \mathrm{~g}$. of bone marrow and $2 \mathrm{~g}$. of lymph glands were examined, the figures for these tissues should be increased four to five and two to three times respectively.

Total antibody (mg.)

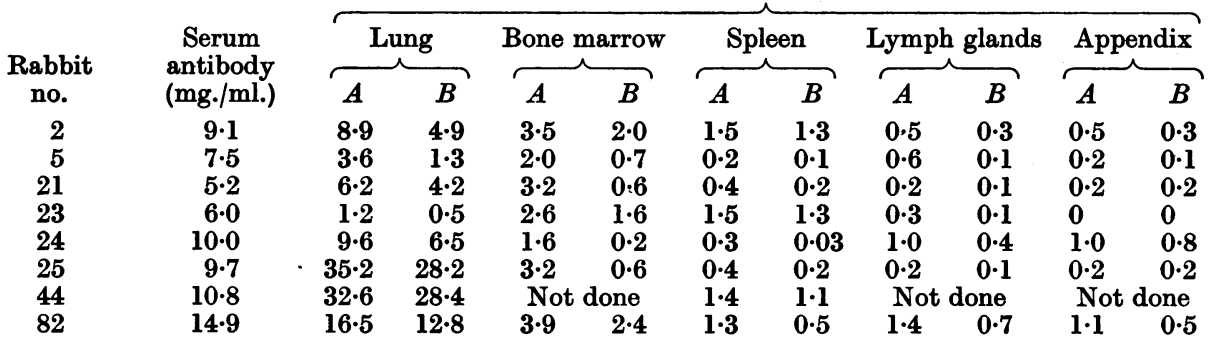

Table 8. Specific activities of intracellular antibody extracted at various time intervals after injection

The total radioactivity of the injected [ $\left.{ }^{14} \mathrm{C}\right]$ amino acids was in all cases $21 \mu \mathrm{C}$. Activities are expressed as counts/min.l mg. of $\mathbf{C}$ and are corrected for extracellular antibody.

\begin{tabular}{|c|c|c|c|c|c|c|c|}
\hline $\begin{array}{c}\text { Rabbit } \\
\text { no. }\end{array}$ & Time & Plasma & Lung & Bone marrow & Spleen & Lymph glands & Appendix \\
\hline 46 & $15 \mathrm{~min}$. & 8 & 480 & Not done & Not done & Not done & Not done \\
\hline 29 & $15 \mathrm{~min}$. & 2 & 1750 & 1890 & $5300^{*}$ & $1930 *$ & $1980^{*}$ \\
\hline 44 & $32 \mathrm{~min}$. & 49 & 1840 & Not done & 3250 & Not done & Not done \\
\hline 49 & $1 \mathrm{hr}$. & 35 & 870 & Not done & Not done & Not done & Not done \\
\hline 28 & $1 \mathrm{hr}$. & 44 & 2320 & 2950 & $1420 \dagger$ & 2460 & $3200^{*}$ \\
\hline 24 & $1 \mathrm{hr}$. & 36 & 2160 & $4000^{*}$ & $8700^{*}$ & 2100 & 1550 \\
\hline 19 & $2 \mathrm{hr}$. & 176 & 975 & 910 & 2650 & 178 & 360 \\
\hline 2 & $2 \mathrm{hr}$. & 103 & 1320 & 375 & 1340 & 174 & 126 \\
\hline 47 & $2 \cdot 2 \mathrm{hr}$. & 278 & 1615 & Not done & Not done & Not done & Not done \\
\hline 5 & $5 \mathrm{hr}$. & 198 & 920 & 435 & $485^{*}$ & Nil & $447 *$ \\
\hline 23 & $5 \mathrm{hr}$. & 215 & 587 & 538 & 872 & $112^{*}$ & No antibody \\
\hline 48 & $5 \mathrm{hr}$. & 188 & 1260 & Not done & Not done & Not done & Not done \\
\hline 21 & $23 \mathrm{hr}$. & 143 & 286 & 280 & 156 & $347^{*}$ & $127^{*}$ \\
\hline 25 & $23 \mathrm{hr}$. & 267 & 438 & 66 & 158 & $192^{*}$ & $214^{*}$ \\
\hline
\end{tabular}

* Amounts of intracellular antibody were very small, and the estimate could be out by a factor of 2.

$\dagger$ Estimate too low. Antibody precipitate was obviously contaminated with other material, and weight was about three times that expected. The value was probably nearer 5000 . 
There was surprisingly little correlation between the antibody content of the plasma and that of the tissues, but it must be remembered that the contribution of any organ to the circulating antibody depends not only on the amount present but on its turnover rate. This will be discussed below.

\section{Specific activity of intracellular antibody}

Table 8 lists the specific ${ }^{14} \mathrm{C}$-activities of antibody in the tissue extracts, after correction for extracellular antibody, but not for contamination with inert material. Once again, there is considerable variation from rabbit to rabbit, which is due at least in part to variation in their immunological responses. Although the number of animals was small, the main trend in lung, spleen and bone marrow is clear enough. Whereas antibody in plasma became increasingly labelled after $15 \mathrm{~min}$., reaching a peak somewhere between 2 and $5 \mathrm{hr}$., antibody labelling in the tissues was already very high at 15 min., reached a peak after about $1 \mathrm{hr}$. and remained higher than that in the plasma for at least $5 \mathrm{hr}$.

These results must be considered in conjunction with those relating to the specific activities of the plasma and tissue free amino acids. They show that antibody is being made in the tissues examined. They also show that the time taken for incorporation of plasma amino acids into antibody molecules within the cells is certainly very much less than $15 \mathrm{~min}$., even though the amounts of labelled antibody which reach the plasma within this period are insufficient to affect the radioactivity of protein in the plasma pool.

\section{RESULTS OF AMINO ACID STUDIES}

\section{Specific activities of free amino acids in plasma after administration of algal-protein hydrolysate}

Comparison of the methods. The turnover of any particular amino acid in the plasma is governed by several factors-notably by the number of metabolic pathways available for its synthesis or degradation and the amounts entering from exogenous and endogenous sources. Furthermore, the contribution of any amino acid to the total free amino acids of plasma or of intracellular fluid, on the one hand, and the proportion incorporated into antibody, on the other, will vary for each amino acid. It would therefore have been ideal, but immensely time-consuming, to have studied several different ${ }^{14} \mathrm{C}$-labelled amino acids individually, by specific isolation and measurement of their radioactivities. We attempted to avoid the need for this by using the mixture of $\left.{ }^{14} \mathrm{C}\right]$ amino acids found in Chlorella-protein hydrolysate, a mixture which contains all the amino acids found in rabbit-serum proteins (except for tryptophan destroyed during hydrolysis) in proportions not unlike those in whole-liver protein. It was reasoned that although some of the injected radioactive amino acids would be diluted more extensively or metabolized more rapidly than others, the average radioactivity of the free amino acids in the plasma, in the intracellular pool, and in the antibody synthesized from it, should be similar.

As already described under Methods, two procedures were used for estimating the specific activity of free amino acids in plasma. In the first the non-protein free amino $\mathrm{N}$ was estimated colorimetrically and this value was multiplied by $\mathbf{4 . 4}$ to approximate to the corresponding weight of amino acid C. [The figure calculated for Chlorellaprotein hydrolysate from the data of Catch (1954) is $4 \cdot 3$, and the corresponding figure from published data on the free amino acids of rabbit plasma is 4.4.] Carbon specific activities were measured, after dilution with inert glycine, and the mean amino acid $\mathrm{C}$ specific activities were calculated on the assumption that the radioactivity came solely from amino acids. This method was convenient, but was based on an assumption which ceased to be strictly true once other radioactive metabolites had been formed.

The second method, namely, specific liberation of terminal carboxyl $\mathrm{C}$ with ninhydrin, was less convenient but its results were independent of the presence of radioactive non-amino acid metabolites, and are therefore more reliable. The two methods were directly compared on plasma samples taken from three rabbits $0 \cdot 25-5 \mathrm{hr}$. after injection of amino acids, and the free amino acid $\mathrm{C}$ specific activities by the second method were $57-71 \%$ (mean $63 \%$ ) of those by the first method. In Table 9 are given the results when $\left[{ }^{14} \mathrm{C}\right]$ amino acids were administered to two series of rabbits and the plasma-free amino acid specific ${ }^{14} \mathrm{C}$-activities were measured in one series by the glycine-dilution method and in the other by the ninhydrin- $\mathrm{CO}_{2}$ method. During the period $0 \cdot 25-5 \mathrm{hr}$. the results were similar to those obtained by direct comparison on the same plasmas, namely, that on the average the true specific activities were $65 \%$ of those obtained by the glycine-dilution method. This relationship was not exact, nor was it necessarily true outside this period of time (in fact, after $1 \mathrm{~min}$., before a significant quantity of metabolic products had appeared in the plasma, the two methods agreed). It could be used as an approximation, however, in later calculations.

Time course of free amino acid specific activity in plasma. In Table 10 are summarized the values for the free amino acid $\mathrm{C}$ specific activities, obtained by the dilution method, at various time intervals after injection of $\left[{ }^{14} \mathrm{C}\right]$ amino acids. 
Table 9. Comparison of specific activities of carbon in free amino acids of plasma, measured by the ninhydrin-carbon dioxide method and by the glycine-dilution method

Rabbits were injected with varied amounts of an algal $\left[{ }^{14} \mathrm{C}\right]$ protein hydrolysate. Specific activities given below have been adjusted to correspond with a dose of $21 \mu \mathrm{c} / \mathrm{rabbit}$, and are therefore comparable with those in Table 8 . Numbers of rabbits used to obtain a mean value are given in parentheses. Separate series of animals were used for each method. For reasons explained in the text the ninhydrin- $\mathrm{CO}_{2}$ method is the more specific. Comparison of the results from the two methods gave the percentages shown in the final column; the average value in the period shown is $66 \%$. Procedures for separation of free amino acids from protein were different in the two methods.

$\begin{array}{cccc}\begin{array}{c}\text { Time of } \\ \begin{array}{c}\text { bleeding after } \\ \text { injection } \\ \text { (min.) }\end{array}\end{array} & \begin{array}{c}\text { Ninhydrin-CO method } \\ \text { mean specific activity } \\ \text { (counts/min./mg. of C) }\end{array} & \begin{array}{c}\text { Mean specific activity } \\ \text { (counts/min./mg. of C) }\end{array} & \begin{array}{c}\text { Radioactivity } \\ \text { from } \alpha \text {-amino } \\ \text { acid C only }\end{array} \\ 15 & 10800(2) & 16000(2) & (\%) \\ 30 & 6300(2) & 10400(2) & 68 \\ 60 & 5350(2) & 6760(4) & 61 \\ 120 & 2500(2) & 3500(3) & 79 \\ 300 & 845(1) & 1700(2) & 50\end{array}$

Table 10. Plasma-free amino acid carbon specific activities (counts/min./mg. of carbon) at various times after injection of $21 \mu \mathrm{C}$ of mixed $\left[{ }^{14} \mathrm{C}\right]$ amino acids

Values were obtained by the dilution method. Those from 15 to $360 \mathrm{~min}$. should be multiplied by 0.65 to give the true values (see text and Table 9). The $3 \mathrm{~min}$. samples were in fact taken after approx. 3 min., which partly accounts for the variable values. The specific activity at zero time was $2.54 \times 10^{6}$; this value was obtained by adding $21 \mu \mathrm{c}$ of mixed $\left[{ }^{14} \mathrm{C}\right]$ amino acids to $100 \mathrm{ml}$. of rabbit serum.

\begin{tabular}{|c|c|c|c|c|c|c|c|c|c|c|}
\hline \multirow{2}{*}{$\begin{array}{c}\text { Rabbit } \\
\text { no. }\end{array}$} & \\
\hline & $\frac{3}{4}$ & $1 \frac{1}{4}$ & 3 & 15 & 30 & 60 & 120 & 240 & 300 & 360 \\
\hline $30 a$ & 465000 & - & - & - & - & - & - & - & - & - \\
\hline $29 a$ & - & 193000 & - & - & - & - & - & - & - & - \\
\hline $27 a$ & - & 189000 & - & - & - & - & - & - & - & - \\
\hline 46 & - & - & 28800 & 15000 & - & - & - & - & - & - \\
\hline 44 & - & - & 27300 & 17000 & 9450 & - & - & - & - & - \\
\hline 49 & - & - & 22100 & - & - & 3620 & - & - & - & - \\
\hline 24 & - & - & 36200 & - & - & 10900 & - & - & - & - \\
\hline 28 & - & - & 32000 & - & - & 7100 & - & - & - & - \\
\hline 47 & - & - & 44500 & - & - & 6150 & 4000 & - & - & - \\
\hline 19 & - & - & $\mathbf{3 4} 300$ & - & - & - & 4130 & - & - & - \\
\hline 2 & - & - & 27800 & - & - & - & 2680 & - & - & - \\
\hline 48 & - & - & 29600 & - & - & - & - & - & 2940 & - \\
\hline 5 & - & - & 106000 & - & - & - & - & - & 1500 & - \\
\hline 23 & - & - & 59300 & - & - & - & - & - & 1950 & - \\
\hline 21 & - & - & 34600 & - & 11400 & - & 3200 & - & - & 950 \\
\hline 25 & - & - & 29700 & 一 & - & 6030 & - & 2040 & - & - \\
\hline
\end{tabular}

Except for those at less than $3 \mathrm{~min}$. (which are included for completeness) the values were all obtained in those rabbits which were used for antibody studies. As already mentioned, the true values at $15-300 \mathrm{~min}$. are probably 0.65 times those given in the table; in Fig. 1, which illustrates graphically the time course of the specific activity of free amino acid $\mathbf{C}$ this correction has been made.

There is considerable variation between individual rabbits, part of which is due to inexact measurement of the shorter time intervals, since we were unaware how rapidly the specific activity was changing. The general picture for the mixed amino acids, however, is very similar to that observed by Henriques, Henriques \& Neuberger (1955) for glycine and by Barry (1952) for lysine and tyrosine. What is apparently a new observation is the extremely rapid fall during the first $3 \mathrm{~min}$. Even when blood was obtained by opening the heart 45 sec. after injection (the shortest period examined) the free amino acids in the plasma contained only $17 \%$ of the injected radioactivity, yet simultaneous injection of the dye Pontamine Sky Blue 6BX (which binds to plasma albumin) showed that complete mixing of the injected material with the plasma had taken place.

Specific activity of free amino acids in the tissues. As already described, the specific activities of the free amino acids in various tissues, at different time intervals after giving $\left[{ }^{14} \mathrm{C}\right]$ amino acids, were measured in a separate series of rabbits. In Table 11 the results are set out. 
After correction to a 'standard' dose of $21 \mu \mathrm{c}$, the plasma-free amino acid $\mathrm{C}$ specific activities lie reasonably close to the curve shown in Fig. 1. The tissue-free amino acid $\mathrm{C}$ specific activities, expressed as a percentage of those in the plasma, increased rapidly during the first $15 \mathrm{~min}$. and thereafter increased slowly or remained very approximately steady for the next $4 \mathrm{hr}$. When the absolute specific activities for tissue amino acids

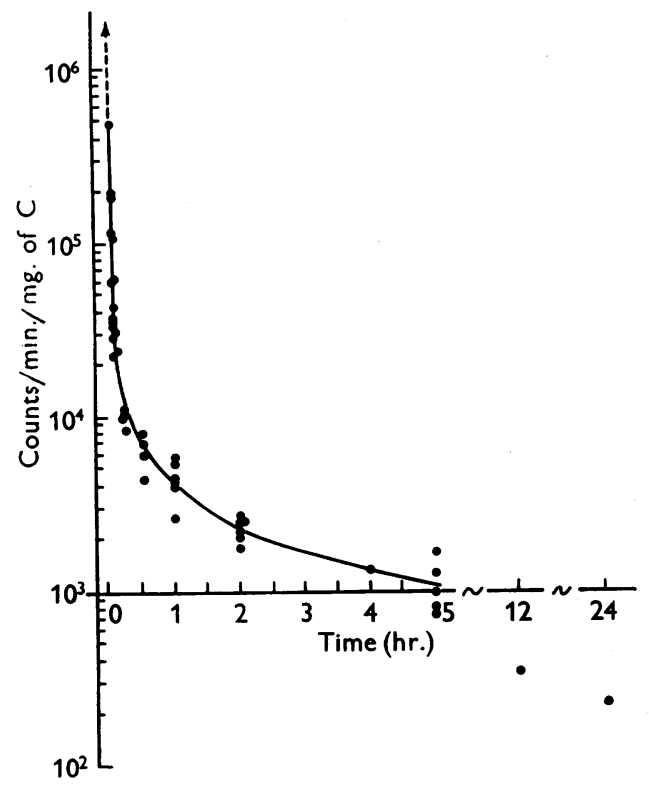

Fig. 1. Specific radioactivity (counts/min./mg. of C) of plasma-free amino acids in rabbits at various times after intravenous administration of $21 \mu \mathrm{c}$ of Chlorella [ $\left.{ }^{14} \mathrm{C}\right]$ protein hydrolysate. The values are taken from all experiments, but those obtained by the dilution method have been corrected to agree with the ninhydrin- $\mathrm{CO}_{2}$ method (see Methods and Table 9). The value at zero time was obtained by adding $21 \mu \mathrm{C}$ of the labelled amino acids to $100 \mathrm{ml}$. of rabbit serum. are plotted (Fig. 2), although erratic, they show curves like that of the plasma-free amino acids but very much flattened. Since the cellular com. position of the different tissues is complex and, except for liver and appendix, varies with the degree of immunization, animal variation is probably a sufficient explanation of the erratic distribution of the points. The low specific activities of the amino acids in spleen and bone marrow, compared with liver, were surprising for such metabolically active tissues. They may indicate that a considerable proportion of the intracellular free amino acids were derived from unlabelled sources (e.g. plasma proteins), or that cells were present (e.g. erythrocytes) whose internal free amino acids equilibrated only slowly with those in plasma. In the bone marrow there may also have been a significant breakdown of cell protein, during the minutes required to remove the tissue into liquid air. The amounts of free amino acid carboxyl $\mathrm{C}$ recovered from $1 \mathrm{~g}$. of the moist perfused tissues corresponded approximately to the following amounts of free amino acid (calculated on the assumption that terminal carboxyl carbon composed $10 \%$ of the amino acid mixture) : liver, $2 \mathrm{mg}$.; appendix, $2.8 \mathrm{mg}$; spleen, $2.4 \mathrm{mg}$.; bone marrow, $2.2 \mathrm{mg}$.; lung, $1.8 \mathrm{mg}$. There was, however, a considerable scatter in the estimate for the last three.

It is possible to estimate graphically from Fig. 2 the approximate mean specific activities of free amino acid $\mathbf{C}$ of the tissues over any given period of time. The values so obtained, however, inevitably apply only to the totality of cells present in the tissue and not to any single type.

\section{DISCUSSION}

The main facts demonstrated above are that, from tissues of hyperimmunized rabbits, intracellular antibody can be extracted and measured; that,

Table 11. Specific activities of free amino acid carbon in rabbit tissues at various times after administering the $\left[{ }^{14} \mathrm{C}\right]$ amino acid mixture

Specific activities were measured by the ninhydrin- $\mathrm{CO}_{2}$ method. Two rabbits were used at each time.

\begin{tabular}{|c|c|c|c|c|c|c|c|c|}
\hline \multirow[b]{2}{*}{ Expt. } & \multirow[b]{2}{*}{$\begin{array}{l}\text { Radioactivity } \\
\text { injected } \\
(\mu \mathrm{c})\end{array}$} & \multirow[b]{2}{*}{$\begin{array}{c}\text { Time after } \\
\text { injection } \\
\text { (min.) }\end{array}$} & \multirow{2}{*}{$\begin{array}{l}\text { Specific activity } \\
\text { of plasma-free } \\
\text { amino acid } \\
\text { (counts/min./ } \\
\text { mg. of } \mathrm{C} \text { ) }\end{array}$} & \multicolumn{5}{|c|}{$\begin{array}{l}\text { Relative specific activity of tissue-free amino acid } \\
\text { ( } \% \text { of plasma values) }\end{array}$} \\
\hline & & & & Lung & $\begin{array}{l}\text { Bone } \\
\text { marrow }\end{array}$ & Spleen & Appendix & Liver \\
\hline $39-40$ & 1.5 & 5 & 3820 & 20 & 7 & 15 & 12 & 29 \\
\hline $41-42$ & $2 \cdot 4$ & 10 & 2280 & 53 & 15 & 19 & 27 & 43 \\
\hline $84-85$ & $2 \cdot 5$ & 15 & 1050 & 52 & 14 & 32 & 39 & 51 \\
\hline $3-5$ & 6 & 30 & 1540 & 31 & 45 & 34 & 81 & 81 \\
\hline $2-6 a$ & 8 & 60 & 1710 & 55 & 66 & 20 & 43 & $17 *$ \\
\hline $1-6$ & 14 & 120 & 1360 & 118 & 66 & 86 & 42 & 74 \\
\hline $4-24$ & 25 & 270 & 1050 & 77 & - & 29 & 108 & 65 \\
\hline
\end{tabular}

* Recovery of carboxyl carbon was much greater than expected, and this value is doubtful. 
after a single intravenous injection of ${ }^{14} \mathrm{C}$-labelled amino acids, such antibody becomes labelled rapidly, being already highly labelled after $15 \mathrm{~min}$., and remaining so for 1-2 hr., after which the radioactivity slowly declines; and that significant labelling of antibody in plasma is not detectable for 20-25 min., after which it increases sharply, reaching a peak between 2 and $4 \mathrm{hr}$.

The interval before labelled proteins appear in the blood stream has been termed the "transit time' by Green \& Anker (1955) and is regarded by them as probably implying that there is some specific delay between the uptake of amino acids by cells, their appearance and synthesis into protein and the release of the protein from the cells into the blood. Since intracellular antibody was found to be extensively labelled in much less than the 'transit time', it is unlikely that the main delay arises at the stage of incorporation of amino acids into soluble protein. Although there may be a lag between formation of new protein molecules and their appearance in soluble form in the cells, this lag must be relatively short. In our view the time course of labelling of plasma antibody can be approximately accounted for by a continuous release of antibody (initially of low radioactivity, because of dilution with a pre-existing unlabelled intracellular pool) from cells in various tissues into the surrounding fluid, followed by passage into the blood stream, to some extent directly across capillary walls, but more commonly by lymphatic pathways of varying length; the whole process being superimposed upon a steady metabolic elimination from the blood stream.

We were interested to see whether our data could be used to calculate the actual turnover of antibody in different tissues, and to assess their relative contributions to antibody synthesis in vivo. Before doing so, however, it is necessary to consider the gross overall mechanisms whereby amino acids could be incorporated both into intracellular and extracellular antibody. Without prejudice to the

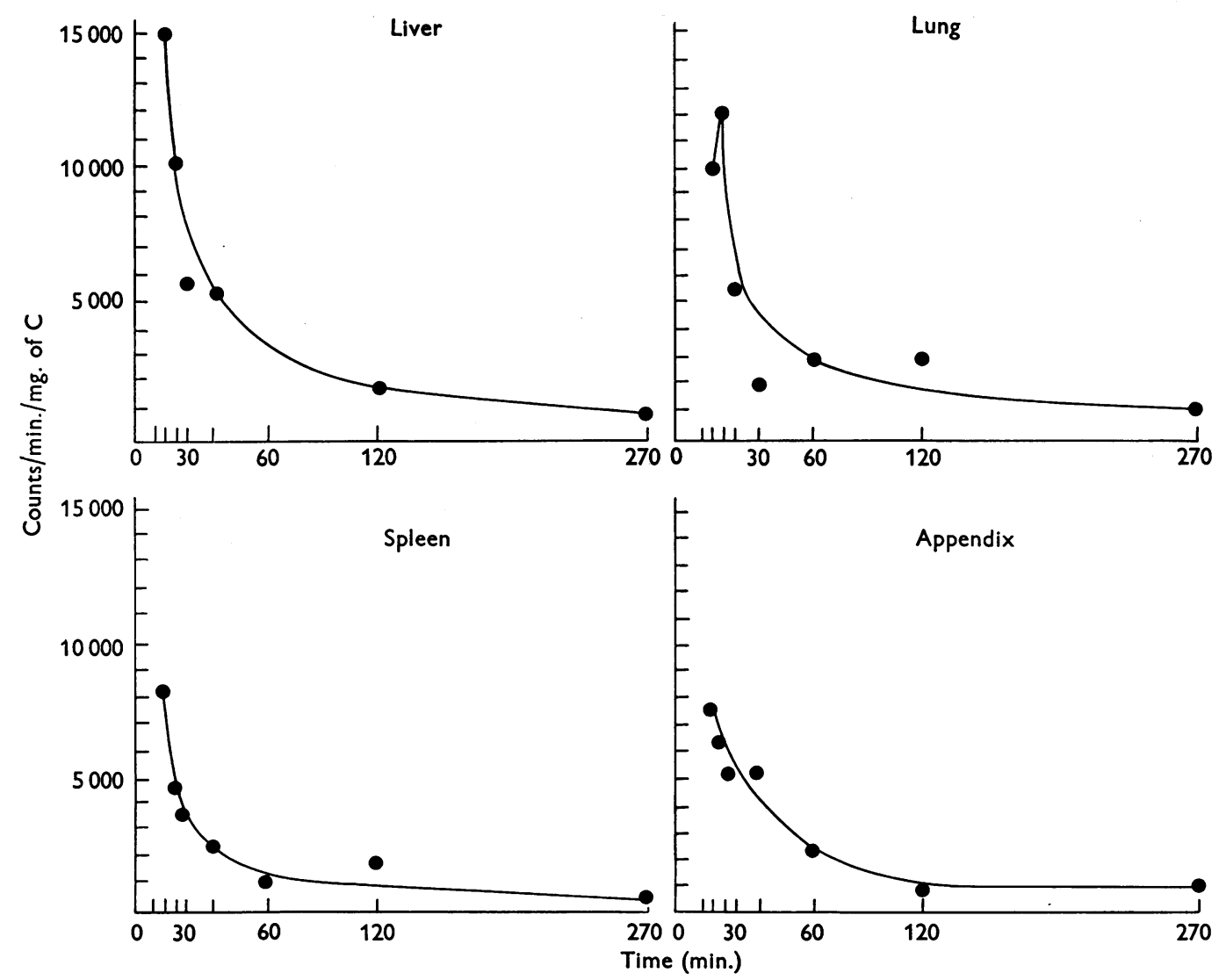

Fig. 2. Specific radioactivity of intracellular free amino acids in different tissues at various times after intravenous administration of $21 \mu \mathrm{c}$ of Chlorella $\left[{ }^{14} \mathrm{C}\right]$ protein hydrolysate. Each point is a mean value from two or more animals. For further details, see text and Table 11. 
details of how amino acids are converted into protein, or to the mechanics of the process of secretion, there are two main possibilities. One is that synthesis of protein occurs close to the cell surface, and that newly formed molecules diffuse both outward into the tissue fluid and inward into the cell, i.e. the secreted antibody does not come from the intracellular antibody pool, and its specific radioactivity therefore resembles that of the intra- or extra-cellular free amino acids rather than that of intracellular antibody. The second possibility is that antibody is formed continuously within the cells from precursors in the free amino acid pool, and that the newly formed molecules mix with a pool of intracellular antibody from which a steady loss occurs into the surrounding fluid. Experiments on antibody production in isolated perfused lungs (B. A. Askonas \& J. H. Humphrey, unpublished work) suggest that the second mechanism is the more probable. It also provides a better explanation of the time course of appearance of radioactive antibody in the blood stream, besides lending itself more readily to simple mathematical treatment. We have therefore adopted the second hypothesis in the calculations given below.

\section{Calculation of turnover rates of intracellular antibody}

Before any calculations are attempted from our data certain assumptions must be made. One is that estimates of the specific activities of intracellular free amino acid made in complex tissues are valid for the particular cells which make antibody. There is at present no way of checking this. A second is that the ${ }^{14} \mathrm{C}$-content of newly formed antibody is the same as the ${ }^{14} \mathrm{C}$-content of the amino acid mixture in the intracellular free amino acid pool as estimated by the ninhydrin-carbon dioxide method. Although all the amino acids administered were equally labelled, and the mixture contained all the amino acids (except tryptophan) in proportions roughly resembling those in a whole-liver hydrolysate (Mütung \& Wortmann, 1954), this assumption is unlikely to be strictly true. The reason for this is that free amino acids in tissues contain a very high proportion of glutamic acid and glutamine. If taurine, which would not be estimated by our methods, is excluded, glutamic acid and glutamine account for a little over half the free amino acids in liver, pancreas or kidney of the cat (Tallan, Moore \& Stein, 1954), whereas glutamic acid accounts for only about $7 \%$ of the amino acids of the Chlorella protein used (Catch, 1954) and about $11 \%$ of the amino acids of rabbit antibody (Smith, McFadden, Stockell \& Buettner-Janusch, 1955). The specific activity of the free amino acids, other than glutamic acid, in the intracellular pool may therefore be considerably underestimated. A third assumption is that all the antibody-forming cells were continuously active during the experiments, i.e. that intracellular antibody was homogeneous and did not consist to any great extent of metabolically inert pre-formed antibody which was stored in some cells and not secreted. This assumption is also probably not strictly true; certainly histological sections examined for antibody by the fluorescent-antibody technique (Coons et al. 1955) showed some cells which contained antibody diffusely throughout the cytoplasm and others which showed antibody in compact granular masses. Furthermore, experiments on the isolated lungs of hyperimmunized rabbits perfused with [ ${ }^{14}$ C] amino acids (B. A. Askonas \& J. H. Humphrey, unpublished work) showed that in about half the cases intracellular and secreted antibody had closely similar radioactivities, which is consistent with the third assumption, but in other cases there was evidence that metabolically inert antibody was also present. Lastly, it is assumed that antibody production is in a steady state, i.e. that the rate of formation of new antibody is equal to the rate of secretion into the tissue fluids.

Suppose that antibody-forming cells in a tissue contain $Q \mathrm{mg}$. of antibody, and that the rate of secretion is $Q / K \mathrm{mg}$./hr. (which is, by assumption, continuous and equal to the rate of synthesis); $K$ will then be the turnover time of the intracellular antibody.

At $t \mathrm{hr}$. after the administration of labelled amino acids let the specific activity of intracellular free amino acid and antibody be respectively $x$ and $y$ counts $/ \mathrm{min} . / \mathrm{mg}$. of C. Suppose that all the antibody secreted in $t \mathrm{hr}$. (Qt/K mg.) were combined, then its specific activity would be

$$
\left(\int_{0}^{t} y \mathrm{~d} t\right) / t
$$

so that total radioactivity in antibody after $t \mathrm{hr}$.

Similarly,

$$
=Q y+\left(Q \int_{0}^{t} y \mathrm{~d} t\right) / K .
$$

total radioactivity added

$$
=\left(Q \int_{0}^{t} x \mathrm{~d} t\right) / K .
$$

These two quantities must always be equal; hence, by differentiation,

and

$$
Q \mathrm{~d} y / \mathrm{d} t+Q y / K=Q x / K,
$$

This equation could be used to find $K$, provided 
that the parameters were known. In the whole animal the amino acid specific activity is changing with time (Fig. 2 and Table 10), and no second theoretical equation relating $\mathrm{d} y / \mathrm{d} t$ to $x$ or $y$ is known. Only a graphical solution is therefore possible. This, however, requires a knowledge of the change in specific radioactivity of intracellular antibody with time, which can be measured only for a series of animals, since each estimation involves killing one of them. The values for lung antibody from different experiments have therefore been combined and a curve has been constructed which could be applied to an 'ideal' hyperimmune rabbit (Fig. 3, in which the values have been corrected for 'purity'). It is recognized that deductions made from such a curve are not applicable to any single experiment and that they must be very approximate. Nevertheless, they are of some interest since they may indicate at least the order of magnitude of the turnover time.

Combining the values from Figs. 2 and 3, and substituting in equation (3), we obtain estimates for $K$ relating to antibody turnover in lung which are given in Table 12. If the theory and the experi-

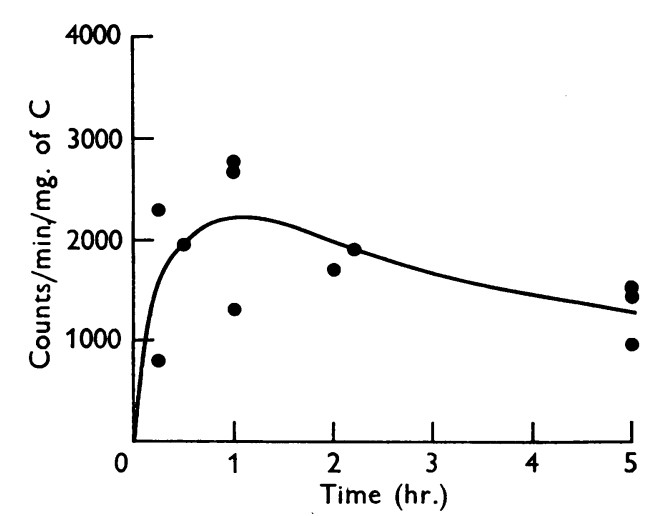

Fig. 3. Specific radioactivity of intracellular antibody in the lungs at different times after intravenous administration of $21 \mu \mathrm{C}$ of Chlorella $\left[{ }^{14} \mathrm{C}\right]$ protein hydrolysate. The values have been corrected for extracellular antibody and for 'purity' (see text). mental results agreed, the curve of intracellular antibody specific activity should show a maximum at a time equal to $K$, at which $x$ and $y$ should be equal. Although the curves could obviously have been drawn somewhat differently, it seems that a value for $K$ of about $2 \mathrm{hr}$. is of the right order. It can, however, be regarded only as very approximate, and will be an underestimate if the specific activity of the amino acids in the intracellular pool has been underestimated.

Similar calculations are not possible for the other tissues, because the experimental values are too few and, owing to the very small weights of antibody recovered, several are not sufficiently reliable for deduction of quantitative conclusions. The turnover time of antibody in spleen is probably rather shorter than that of antibody in lung, since the radioactivity of the former was greater during the first hour after administration of the label, but after $5 \mathrm{hr}$. or more was less. The turnover times in bone marrow, lymph glands and appendix are probably similar to that in lung.

It is possible to test whether these estimates of turnover time are reasonable by taking them in conjunction with the measurements of intracellular antibody (Table 7) corrected for partial recovery (Table 1), and comparing the calculated rate of antibody secretion with that required to maintain the observed levels of antibody in serum. A $2.5 \mathrm{~kg}$. rabbit, in a steady state, with a serum-antibody level of $10 \mathrm{mg} . / \mathrm{ml}$., has about $2.4 \mathrm{~g}$. of antibody in the blood and tissue fluid, and replaces in $24 \mathrm{hr}$. about $10 \%$ of its circulating antibody, i.e. about $240 \mathrm{mg}$. If the average turnover time of intracellular antibody in all tissues were $2 \mathrm{hr}$. this would require $20 \mathrm{mg}$. of total intracellular antibody, i.e. the total amount of intracellular antibody should be about equal to the quantity of antibody contained in $2 \mathrm{ml}$. of serum.

The actual recoveries of intracellular antibody from lung, bone marrow, spleen, lymph glands and appendix, after allowing for partial recovery and assuming a total of $30 \mathrm{~g}$. of active bone marrow and $6 \mathrm{~g}$. of lymph glands, lie between 72 and $200 \%$ (mean $144 \%$ ) of the antibody in $2 \mathrm{ml}$. of serum.

\section{Table 12. Calculation of turnover time of intracellular antibody in lung}

The turnover time, $K$, is calculated from the equation $\mathrm{d} y / \mathrm{d} x=(x-y) / K$ (see text). Values of $x$ and $y$ were obtained from the curves shown in Figs. 2 and 3 respectively. Approximate values for $\mathrm{d} y / \mathrm{d} t$ were obtained graphically from the curve shown in Fig. 3.

$\begin{array}{ccccc}\begin{array}{c}\text { Time } \\ \text { (hr.) }\end{array} & \begin{array}{c}x \\ \text { (counts/min./mg. of C) }\end{array} & \begin{array}{c}y \\ \text { (counts/min./mg. of C) }\end{array} & \begin{array}{c}\mathrm{d} y / \mathrm{d} t \\ (\mathrm{hr} .)\end{array} \\ \frac{1}{4} & 6000 & 1500 & 2500 & 1 \cdot 8 \\ \frac{1}{2} & 4500 & 2000 & 1150 & 2 \cdot 2 \\ \frac{3}{2} & 3500 & 2100 & 600 & 2 \cdot 3 \\ 2 & 1800 & 1950 & -350 & 0 \cdot 4 \\ 3 & 1400 & 1700 & -200 & 1 \cdot 5 \\ 5 & 900 & 1300 & -170 & 2 \cdot 4\end{array}$


This finding suggests that the estimates are of the right order, although an average turnover time of $3 \mathrm{hr}$. would give better agreement.

\section{Sites of antibody production}

This series of experiments was confined to rabbits hyperimmunized by intravenous injection of a particular bacterial antigen, and the results are not necessarily true for other species, or for immunization by other antigens or by other routes. With this proviso, it may be said that the chief source of antibody in most animals was the lung tissue, and that the next most important source (occasionally the main source) was the bone marrow. The spleen contributed less than the bone marrow, but usually more than the lymph glands and appendix. The liver and kidneys never contained significant quantities of antibody. There was, however, a marked variation from animal to animal in the contribution by the other tissues examined. Apart from their emphasis on the lungs, which have not usually been regarded as important sources of antibody, the conclusions agree generally with those of other workers. They are also in good agreement with results obtained in rabbits by incubation of tissue slices with $\left[{ }^{14} \mathrm{C}\right]$ amino acids in vitro (B. A. Askonas \& J. H. Humphrey, unpublished work). Other results obtained by the in vitro method (Askonas \& White, 1956) on guinea pigs which received ovalbumin with adjuvant in the foot pad, showed a quite different distribution of antibody synthesis, nearly all being made in the bone marrow and lymph glands, with very little in the spleen and none in the lung.

\section{Turnover of plasma-free amino acids}

An observation of some interest, although only incidental to this work, is the extremely rapid turnover of plasma-free amino acids. Threequarters of a minute after injection of labelled amino acids there remained in the plasma less than $20 \%$; at $3 \mathrm{~min}$. only about $2 \%$; and at $5 \mathrm{~min}$. only $1 \%$. A large part of the drop in radioactivity of the plasma-free amino acids is due to very rapid diffusion from the blood into the extravascular fluid. If such diffusion occurred freely and completely into the whole of the extravascular water (the volume of which may be taken as approximately $25 \%$ of the rabbit's weight or about six times the plasma volume; Manery, 1954), the radioactivity would be expected to drop to $16 \%$ in the absence of any removal into cells. Thus neglecting changes which took place during separation of plasma in vitro, and any return from cells to extracellular fluid, the observed drop to $1 \%$ in 5 min. must be due to the entry of extracellular amino acids into cells, at a rate corresponding to a half-life of not more than $1.25 \mathrm{~min}$. If the amino acids throughout the extracellular space were all equally available for exchange with cells, this would imply that in a $2.5 \mathrm{~kg}$. rabbit, whose plasma and extracellular fluid contained amino acids at a concentration of, say, $40 \mathrm{mg} . / 100 \mathrm{ml}$., some $100 \mathrm{mg}$. of amino acids entered (and left) the cells every minute. The extracellular water is, in fact, far from homogeneous, and exchange of amino acids between it and the cells is relatively slow in muscle (Henriques et al. 1955) and is likely to be slow in the relatively acellular connective tissue and skin. The extracellular water of these tissues comprises between them some 60-65\% of the whole. If diffusion of labelled amino acids from these spaces back into the bloodstream were slow compared with the rate of disappearance of the label into cells in other tissues, the result would be that the above estimate of the rate of exchange of amino acids between cells and their surroundings was too high.

It can be seen from Fig. 1 that after about $5 \mathrm{~min}$. the rate of decline of free amino acid specific activity in the plasma diminishes markedly, presumably because re-entry of the label from the cells becomes significant, and by $12 \mathrm{hr}$. it has become quite slow. The immediate fate of the labelled amino acid molecules when they leave the blood stream is of considerable interest. In a recent review McFarlane (1957) points out that inside $5 \mathrm{~min}$. more than $90 \%$ of injected amino acid radioactivity leaves the lymph and plasma, conclusions based on calculation rather than direct measurement, but closely similar to our own. It is a commonly accepted hypothesis that, after mixing with the plasma and tissue fluids, the injected molecules come rapidly into equilibrium with an intracellular free amino acid pool, which is in turn in equilibrium with the tissue proteins. McFarlane (1957) regards the existence of a true intracellular free amino acid pool of any size as improbable, and prefers the hypothesis that the pool consists in fact of a labile intracellular protein which is in process of rapid exchange with free amino acids. Provided that equilibrium between labile protein and intracellular free amino acids were sufficiently rapid, and that the protein were so unstable as to become largely hydrolysed to free amino acids during experimental handling of the tissues, either hypothesis could accommodate our results. As will be shown, however, the size of the intracellular pool, whether of free amino acids or of labile protein, must be quite considerable and in the absence of direct evidence for any labile protein in large enough amounts, it is simpler to consider a real pool of intracellular free amino acids. Henriques et al. (1955), using a technique which might be expected to avoid post-mortem changes, found that in rabbits injected with 
$\left.{ }^{[14} \mathrm{C}\right]$ glycine maximum labelling of tissue proteins does not occur until after an hour or more. Even in mice, Borsook, Deasy, Haagen-Smit, Keighley \& Lowry (1950) found $30-80 \%$ of visceral-intracellular radioactivity to be in non-protein form $10 \mathrm{~min}$. after injection of various labelled amino acids. Maximum labelling of plasma proteins in the rabbit takes about $3 \mathrm{hr}$., and it is therefore clear that loss of ${ }^{14} \mathrm{C}$ by incorporation into any relatively stable proteins cannot be of much importance in considering what happens to the labelled amino acids during the first few minutes after intravenous injection of tracer doses. As has already been stated, within $5 \mathrm{~min}$. the specific radioactivity of free amino acids in the plasma has fallen to about one-hundredth of the calculated initial value. Since only a drop of about sixfold can be accounted for by mixing with amino acids in the extravascular extracellular fluid, the effective size of the rapidly equilibrating intracellular free amino acid pool must be at least 16 times as great as the total extracellular free amino acid pool (or 100 times the free amino acid pool in the plasma). If there is twice as much intracellular water as extracellular (approximate value from Manery, 1954), this would imply that on average cell water contains a concentration of readily exchangeable free amino acids eight times that in the plasma. This conclusion is in approximate agreement with the finding of Christensen, Streicher \& Elbinger (1948) that in guinea pigs the concentration of $\alpha$-amino nitrogen in liver water is about 16 times and in muscle about six times that in the plasma. A further deduction is that $5 \mathrm{~min}$. after injection of $21 \mu \mathrm{C}$ of algal-protein hydrolysate the specific activity of the intracellular amino acids would average not more than about 25000 counts/min./ mg. of carbon. The effects of dilution due to a rapid intracellular turnover of unlabelled glutamic acid; of disappearance of the labelled amino acids into intracellular protein; or of mixing with unlabelled amino acids produced by autolysis post mortem will all be to lower this figure. Thus the fact that the observed values corresponded to 15000 counts/ min./mg. of carbon in liver, 10700 in lung and 8000 in spleen may also be taken to indicate that our reasoning, despite the numerous assumptions and approximations, is in essence valid.

\section{SUMMARY}

1. Intracellular antibody was recovered from tissues of rabbits hyperimmunized by intravenous injections of type 3 pneumococci, and perfused free of blood at various time intervals after administration of ${ }^{14} \mathrm{C}$-labelled amino acids. Allowance was made for pre-formed extracellular antibody by injecting ${ }^{131}$ I-labelled antibody 2-3 days before- hand, and allowing it to come into equilibrium with antibody in the extracellular fluid.

2. ${ }^{14} \mathrm{C}$-Labelled antibody was found in lungs, bone marrow, spleen, lymph glands and appendix (but not in liver or kidneys) within a few minutes of adminstering the label, and before ${ }^{14} \mathrm{C}$ was detectable in plasma antibody.

3. The amounts of intracellular antibody recovered from tissues were: lung $>$ bone marrow $\geqslant$ spleen $\geqslant$ lymph glands $\geqslant$ appendix.

4. The time course was determined of the specific ${ }^{14} \mathrm{C}$-activities of intracellular antibody and, of the intracellular free amino acids in various tissues, and of the plasma-free amino acids. From the results the 'turnover time' of intracellular antibody in the lung was calculated to be of the order of $2 \mathrm{hr}$.

5. From consideration of the total amounts of intracellular antibody recovered, and of the daily production of antibody required to maintain the observed plasma levels, the average 'turnover time' of all tissue antibody was calculated to be of the order of $3 \mathrm{hr}$.

6. Consideration of the time course of plasmafree amino acid specific activities during the first few minutes after injection of a mixture of ${ }^{14} \mathrm{C}$ labelled amino acids suggests (for a $2.5 \mathrm{~kg}$. rabbit) that (i) the rate of exchange of amino acids between cells and tissue fluids is of the order of $100 \mathrm{mg}$./ min., and (ii) the size of the 'intracellular free amino acid pool' with which this rapid exchange occurs is of the order of 100 times the plasma-free amino acid pool.

We are much indebted to Miss Rosemary Willson for her skilled technical assistance; to the staff of the Department of Biophysics and Optics for much help with the isotopic work, in particular to Mr R. C. Holloway for the iodinations with 131I; and to Mr G. Dickinson and Mr P. R. Purser for the gas counting of ${ }^{14} \mathrm{C}$. We would also like to thank $\mathrm{Dr}$ T. S. Work, Dr A. S. McFarlane and Dr C. Matthews for valuable advice and discussion.

One of us (B.D.S.) expresses his gratitude to the Humanitarian Trust Fund and the Friends of the Hebrew University of Jerusalem for a maintenance grant throughout the period of this investigation.

\section{REFERENCES}

Askonas, B. A. \& White, R. G. (1956). Brit. J. exp. Path. 37,61 .

Barry, J. M. (1952). J. biol. Chem. 195, 795.

Borsook, H., Deasy, C. L., Haagen-Smit, A. J., Keighley, G. \& Lowry, P. H. (1950). J. biol. Chem. 187, 839.

Bradley, J. E. S., Holloway, R. C. \& McFarlane, A. S. (1954). Biochem. J. 57, 192.

Bruce, H. M. \& Parkes, A. S. (1940). J. Hyg., Camb., 44, 501.

Catch, J. R. (1954). Proc. 2nd Radioisotope Conference, vol. 1, p. 258. London: Butterworths Scientific Publications. 
Christensen, H. N., Streicher, J. A. \& Elbinger, R. L. (1948). J. biol. Chem. 172, 515.

Cohen, S., Holloway, R. C., Matthews, C. \& McFarlane, A. S. (1956). Biochem. J. 62, 135.

Coons, A. H. \& Kaplan, M. H. (1950). J. exp. Med. 91, 1. Coons, A. H., Leduc, E. H. \& Connolly, J. M. (1955). J. exp. Med. $102,49$.

Duchateau, G. \& Florkin, M. (1954). Arch. int. Physiol. 62 , 205.

Ehrich, W. E. \& Harris, T. N. (1942). J. exp. Med. 76, 335.

Fagraeus, A. (1948). Acta med. scand. 130, Suppl. 204.

Green, H. \& Anker, H. S. (1955). J. gen. Physiol. 38, 283.

Heidelberger, M., Kendall, F. E. \& Scherp, H. W. (1936). J. exp. Med. 64, 559.

Henriques, O. B., Henriques, S. B. \& Neuberger, A. (1955). Biochem. J. 60, 409.

Humphrey, J. H. \& McFarlane, A. S. (1954). Biochem. J. $57,186$.

Kauffman, F., Björneboe, M. \& Vammen, B. (1938). Z. Hyg. InfektKr. 121, 36.

McFarlane, A. S. (1956). Biochem. J. 62, 135.
McFarlane, A. S. (1957). Progr. Biophys. 7, 123.

McMaster, P. D. \& Hudack, S. S. (1935). J. exp. Med. 61, 783.

Manery, J. F. (1954). Physiol. Rev. 34, 342.

Mütung, D. \& Wortmann, V. (1954). Biochem. Z. 325, 448.

Oakley, C. L., Batty, I. \& Warrack, G. H. (1951). J. Path. Bact. 63, 33.

Oakley, C. L., Warrack, G. H. \& Batty, I. (1949). J. Path. Bact. 61, 179.

Pfeiffer, R. \& Marx (1898). Z. Hyg. InfektKr. 27, 272.

Russell, J. A. (1944). J. biol. Chem. 156, 467.

Smith, E. L., McFadden, M. L., Stockell, A. \& BuettnerJanusch, V. (1955). J. biol. Chem. 214, 197.

Stavitsky, A. B. (1955). J. Immunol. 75, 214.

Sterzl, J. (1955). Czech. Fol. Biol. 1, 193.

Tallan, H. H., Moore, S. \& Stein, W. H. (1954). J. biol. Chem. 211, 927.

Topley, W. W. C. (1930). J. Path. Bact. 33, 339.

Van Slyke, D. D., McFadyen, D. A. \& Hamilton, P. (1941). J. biol. Chem. 141, 671 .

\title{
The Excretion of Microgram Doses of Hexoestrol by Rabbits and Rats
}

\author{
By E. C. DODDS, S. J. FOLLEY, R. F. GLASCOCK AND W. LAWSON \\ The Courtauld Institute of Biochemistry, Middlesex Hospital, W. 1, \\ and
}

The National Institute for Research in Dairying, University of Reading

(Received 9 July 1957)

Extremely small doses of all the closely related synthetic female sex hormones are capable of producing a physiological response in laboratory animals. The effective subcutaneous dose of mesohexoestrol for a rat is $0.2 \mu \mathrm{g}$. (Dodds et al. 1944), and from work on mice it appears that about a two-hundredth of the subcutaneous dose is effective when administered locally to the vagina (Emmens, 1940-41). The metabolism of such extremely potent substances is clearly of considerable interest, and this interest is heightened by their well-known use in cancer, particularly carcinoma of the prostate. Treatment with oestrogens causes a temporary regression of the malignancy, which, however, recurs after varying intervals of time when they are no longer effective. This was noted by Smith \& Williams (1948), who suggested that the failure of continued treatment might be due to an alteration in the metabolism of the drug. Metabolism of female sex hormones is also of interest from the point of view of the induction of artificial lactation and of the fattening of cattle.

As pointed out by Hanahan, Daskalakis, Edwards \& Dauben (1953) studies on the metabolism of oestrogens have been carried out in the main through the massive doses which were necessitated by the relatively insensitive methods available for their detection in the excreta and tissues of the experimental animals. The isotopic tracer method is particularly suited to the elucidation of this problem because of the very small amounts of radioactive substances which can be detected. Such a method was applied by Albert, Heard, Leblond \& Saffran (1949), who studied the metabolism of $\left[{ }^{131} I\right]$ iodo- $\alpha$-oestradiol after injection into mice at doses ranging from $1.7 \mu \mathrm{g}$ to $2 \mathrm{mg}$. The iodo-compound, unlike the parent oestradiol, however, is not physiologically active even at doses as high as $100 \mu \mathrm{g}$. and this, coupled with the fact that the actual doses used were mostly very much higher than was the effective dose of oestradiol itself, somewhat detracts from the value of the work. However, these workers note that the outstanding feature of the metabolism of their compound was accumulation in the gastrointestinal tract, which agrees with what has been found for physiologically active oestrogens.

Twombly (1951) and Twombly \& Schoenewaldt (1951) have studied the metabolism in female mice of ${ }^{14} \mathrm{C}$-labelled stilboestrol administered in doses of about $2 \mathrm{mg}$., which is more than a thousand times the effective physiological dose. They found that most of the dose was excreted in $21 \mathrm{hr} ., 70-85 \%$ by way of the faeces and 15-30\% by way of the

Bioch. 1958, 68 